\title{
Investigation of the Effect of Hyperforin and Hypericin on Inflammatory Response in RAW 264.7 Macrophages
}

\author{
Hiperforin ve Hiperisinin RAW 264.7 Makrofajında Inflamatuar Yanıt Üzerine \\ Etkisinin Incelenmesi
}

\author{
Mehmet Berköz $^{1^{*}}$, Oruc Allahverdiyev ${ }^{2}$, Metin Yıldırım ${ }^{3}$ \\ ${ }^{1}$ Department of Pharmaceutical Biotechnology, Faculty of Pharmacy, Van Yuzuncu Yil University, Van, Turkey \\ ${ }^{2}$ Department of Pharmacology, Faculty of Pharmacy, Van Yuzuncu Yil University, Van, Turkey \\ ${ }^{3}$ Department of Biochemistry, Faculty of Pharmacy, Mersin University, Mersin, Turkey
}

\begin{abstract}
Objective: This study aims to determine the antiinflammatory property of hypericin and hyperforin using in vitro model.

Materials and Methods: In this study, 0, 25, 50, 75 and $100 \mathrm{nM}$ hyperforin and $0,2.5,5,7.5$ and $10 \mu \mathrm{M}$ hypericin were treated to lipopolysaccharide (LPS) stimulated RAW 264.7 macrophages. We aimed to display the antiinflammatory effects of hypericin and hyperforin via measuring prostaglandin $\mathrm{E}_{2}\left(\mathrm{PGE}_{2}\right)$ and nitric oxide (NO) production and cyclooxygenase-2 (COX-2) and inducible nitric oxide synthase (iNOS) gene expression in LPS induced RAW 264.7 macrophages.

Results: Our study has shown that all applied concentration of hyperforin and hypericin decreased nitric oxide (NO) production and inducible nitric oxide synthase (iNOS) and cyclooxygenase-2 (COX-2) gene expression in RAW 264.7 macrophages, significantly. Similarly, all applied concentration of hyperforin and hypericin decreased prostaglandin $\mathrm{E}_{2}\left(\mathrm{PGE}_{2}\right)$ production but this decrease was statistically significant only in groups treated with 75 and $100 \mathrm{nM}$ hyperforin and 7.5 and $10 \mu \mathrm{M}$ hypericin.

Conclusion: This indicates that hyperforin and hypericin inhibited $\mathrm{NO}$ and $\mathrm{PGE}_{2}$ production and $i N O S$ and $C O X$ 2 gene expression in RAW 264.7 macrophages in a dosedependent manner. Inhibition of $\mathrm{NO}$ and $\mathrm{PGE}_{2}$ production by hyperforin and hypericin is a result of the inhibition of $i N O S$ and COX-2 gene expression. For this reason, it is possible to say that hypericin and hyperforin can be used to reduce the inflammatory response.
\end{abstract}

Key Words: Hypericin, hyperforin, RAW 264.7, nitric oxide, prostaglandin $\mathrm{E}_{2}$

\section{Introduction}

Acute inflammatory response represents an initial protective mechanism in the body $(1,2)$. However,

\section{ÖZET}

Amaç: Bu çalışma in vitro model kullanarak hiperisin ve hiperforinin anti-inflamatuvar özelliğini belirlemeyi amaçlamaktadır.

Gereç ve Yöntem: Bu çalışmada, lipopolisakkarit (LPS) ile uyarılmış RAW 264.7 makrofajları, $0,25,50,75$ ve 100 $\mathrm{nM}$ hiperforin ve $0,2,5,5,7,5$ ve $10 \mu \mathrm{M}$ hiperisin ile muamele edilmiştir. LPS ile indüklenmiş RAW 264.7 makrofajlarında, prostaglandin $\mathrm{E}_{2}\left(\mathrm{PGE}_{2}\right)$ ve nitrik oksit (NO) üretimi ile siklooksijenaz-2 (COX-2) ve indüklenebilir nitrik oksit sentaz (iNOS) gen ekspresyonunu ölçerek hiperisin ve hiperforinin antienflamatuar etkilerini göstermeyi amaçladık.

Bulgular: Yaptığımız çalışma, uygulanan tüm hiperforin ve hiperisin konsantrasyonlarınin, RAW 264.7 makrofajlarında nitrik oksit (NO) üretimini ve indüklenebilir nitrik oksit sentaz (iNOS) ve siklooksijenaz 2 (COX-2) gen ekspresyonlarını önemli ölçüde azalttı̆̆ını göstermektedir. Benzer bir şekilde, uygulanan tüm hiperforin ve hiperisin konsantrasyonlarının prostaglandin $\mathrm{E}_{2}\left(\mathrm{PGE}_{2}\right)$ üretimini azalttığ1 ancak bu düşüşün sadece 75 ve $100 \mathrm{~nm}$ hiperforin ile 7,5 ve $10 \mu \mathrm{M}$ hiperisin uygulanan gruplarda istatistiksel olarak anlamli olduğu görülmüştür.

Sonuç: Bu durum, hiperforin ve hiperisinin doza bağımlı bir şekilde RAW 264.7 makrofajlarındaki $\mathrm{NO}$ ve $\mathrm{PGE}_{2}$ üretimini ve $i N O S$ ve $C O X-2$ gen ekspresyonunu inhibe ettiğini göstermektedir. $\mathrm{Bu}$ nedenle, hiperisin ve hiperforinin inflamatuar yanıtı azaltmak için kullanılabileceğini söylemek mümkündür.

Anahtar Kelimeler: Hiperisin, hiperforin, RAW 264.7, nitrik oksit, prostaglandin $\mathrm{E}_{2}$

excessive and chronic inflammation results in severe damage of cells and tissues (3). Emerging evidences support the hypothesis that chronic inflammation plays a critical role in various 
pathological conditions, including atherosclerosis, autoimmune disorders, neurodegenerative diseases, and inflammation related various human cancers $(4,5)$.

Nitric oxide (NO) is enzymatically formed from the terminal guanidine-nitrogen of L-arginine by a group of enzymes called nitric oxide synthesis (NOS) (6). The enzymes are classified into three isoforms; endothelial NOS (eNOS), neuronal NOS (nNOS) and inducible NOS (iNOS). eNOS is a constitutive enzyme present primarily in endothelium. nNOS is a neurally associated constitutive NOS. iNOS is an inducible enzyme the expression of which in macrophages, neutrophils, endothelium and epithelium is induced by LPS and several cytokines. iNOS can produce relatively large concentrations of $\mathrm{NO}$ for a long time and therefore, has been associated with pathophysiological events $(7,8)$.

Cyclooxygenases (COXs) are the key enzymes required for the synthesis of prostaglandins (PGs) from arachidonic acid. Cyclooxygenases has three known forms; COX-1, COX-2 and COX-3. COX1 is constitutively expressed in the gastrointestinal tract and is considered to be responsible for maintaining mucosal integrity. COX-2 is induced by pro-inflammatory mediators and involved in the amplification of inflammation and pain. On the other hand, COX-3 enzyme is expressed only in the brain. COX-2 expression could be induced in neutrophils, monocytes and endothelial cells by many cytokines including IL-1 and TNF- $\alpha$ (9). When COX-2 expression is induced in cells, a proportionately larger amount of $\mathrm{PGE}_{2}$ is produced by non-enzymatic conversion. For this reason, COX products, mainly $\mathrm{PGE}_{2}$ are wellknown mediators of the cardinal features of inflammation-pain, oedema, erythema and warmth (10).

Hypericum perforatum L. is a member of Hypericaceae family. It is a herbaceous perennial plant native to Asia and Europe. At present, they are either naturally occurring on, or which have been introduced to, every continent in the world, except Antarctica. It is a beneficial plant used in America and Europe for medical properties (11). It contains lots of biologically active compounds including; naphtodianthrones (hypericin and pseudohypericin), prenylated acylphloroglucinols (hyperforin and adhyperforin), flavonoids (quercetin, hyperoside, rutin, and quercitrin), essential oil rich in sesquiterpenes, and xanthones (1,3,6,7-tetrahydroxyxanthone) (12). In medicine, extracts of Hypericum have an extensive range of pharmacological properties, the best important utilization of Hypericum perforatum $\mathrm{L}$ is using for treatment of mild to moderate depression and currently it has an important role in the treatment of depressive disorder taking into account of these pharmacological activities, Hypericum perforatum L. preparations appear as one of the major herbal dietary supplements in the whole world, also it has antiviral, antitumoral, antimicrobial, antioxidant and antiinflammatory activities and it is used for treatment of wound healing $(11,12)$.

The most common compounds in Hypericum perforatum L. are hypericin and hyperphorin. Hypericin has been at the forefront of many studies investigating anti-viral, anti-cancer, anti-depressive and anti-microbial activities. On the other hand, hyperforin has anti-depressive, anti-bacterial, antituberculosis and anti-fungal activities (13). Although many biological activities of hypericin and hyperforin are well kwown, what role it plays in the inflammatory response is not yet known $(13,14)$.

This study was designed to estimate the inhibitory effects of hyperforin and hypericin on inflammatory response by LPS stimulation in RAW 264.7 macrophages via measuring the production of $\mathrm{NO}$ and $\mathrm{PGE}_{2}$ and $\mathrm{mRNA}$ expression of $i \mathrm{NOS}$ and COX2.

\section{Materials and Methods}

\section{Cell culture}

RAW 264.7 macrophages were purchased from American Type Culture Collection (ATCC) and the cells were incubated at $37^{\circ} \mathrm{C}$ and $5 \% \mathrm{CO}_{2}$. All the chemicals used in our study were purchased from Sigma-Aldrich and Merck companies and all products were in cell culture purity. The cells were passaged when they were cultivated at a density of $70 \sim 80 \%$ full of the dish. Medium was removed and $1 \times$ Phosphate buffered saline (PBS) was used to wash the dish. We subsequently tapped the dish and used fresh medium to wash down the cells. The fallen cells were collected in centrifuge tube, and we centrifuged the tube with $1000 \mathrm{rpm}$ for 5 minute. After that, the supernatant was sucked up and the pellet was dispersed by fresh medium. Finally, the cells were seeded in dishes or wells with a proper density.

After the cells grew stably and reached at a density of $2-3 \times 10^{6}$ cells $/ \mathrm{mL}$, the medium was removed and $1 \times$ PBS was used to gently wash the dish. The medium was replaced serum-free DMEM. The cells were induced by incubation in medium containing $0.1 \mu \mathrm{g} / \mathrm{mL}$ LPS (E. coli 0127: E8). 
Hyperforin and hypericin were dissolved in DMEM. These dissolution compounds were treated cells together with LPS.

\section{Cell viability assay}

The cellular toxicity of hyperforin and hypericin were determined by (3-(4,5-Dimethylthiazol-2-yl)2,5-Diphenyltetrazolium Bromide (MTT) assay (15). After $24 \mathrm{hr}$ of incubation with the cells, hyperforin and hypericin were removed by washing the cultured cells three times with medium. Then, the cells were collected by centrifugation and the pellets were suspended in fresh medium. The MTT solution was prepared using phosphate buffered solution (PBS) at 5 $\mathrm{mg} / \mathrm{mL}$ concentration. MTT solution was added to the culture plate with cells and then incubated at $37^{\circ} \mathrm{C}$ for 4 hours. The solution of $0.4 \mathrm{~N} \mathrm{HCl}$ in isopropyl alcohol was added to the culture well to dissolve the formed tetrazolium salt. The results were measured by ELISA which read the absorption at $540 \mathrm{~nm}$ in ELISA microplate reader (Thermo Fisher Scientific, Wathham, MA, USA). The experiment was repeated by three times. Medium without cells was used as blank.

\section{Determination of NO production}

Nitrite and peroxynitrite levels in the cell supernatant were measured using the Griess method (16) to determine NO level in the cell culture medium. Nitrite and peroxynitrite are stable end products of $\mathrm{NO}$ in in vitro system. By this way, the level of NO synthesis by iNOS can be evaluated. Griess reagent was prepared by mixing 1 volume of $1 \%$ sulfanilamide solution and 1 volume of $0.1 \% \quad \mathrm{~N}$-1-naphthyl ethlenediamine dihydrochloride prepared in $2.5 \%$ $\mathrm{H}_{3} \mathrm{PO}_{4}$. Tested cells were treated by $0.1 \mu \mathrm{g} / \mathrm{mL}$ LPS. The tested compounds were added in gradient concentrations into the medium with cultured cells before the adding of the stimulants. After $24 \mathrm{hr}, 48 \mathrm{hr}$ and $72 \mathrm{hr}$ of stimulation, $50 \mu \mathrm{L}$ of supernatant of the culture wells was taken and mixed with $50 \mu \mathrm{L}$ freshly prepared Griess reagent. After incubation at room temperature for 10 minutes, the ELISA plate was centrifuged for 5 minutes at $1000 \mathrm{rpm}$. The results were obtained from ELISA by reading the absorption at $540 \mathrm{~nm}$. This reaction was repeated three times for each sample. Accumulation of nitrite was calculated as nmol of nitrite per $10^{6}$ cells from three independent experiments. The culture medium without cells was used as blank. Sodium nitrate $\left(\mathrm{NaNO}_{2}\right)$ was diluted to $3 \mu \mathrm{M}, 25 \mu \mathrm{M}, 50 \mu \mathrm{M}$ and $100 \mu \mathrm{M}$ and used as standard solutions.

\section{Determination of $\mathrm{PGE}_{2}$ production}

Prostaglandins (PGs) are lipid compounds derived from arachidonic acid. Like all $\mathrm{PGs}, \mathrm{PGE}_{2}$ can be produced by several tissues including the gut, the uterus, blood vessels, bladder, placenta, brain and cells of the immune system. In some pathologic conditions such as tissue injury, inflammation and many cancers the production of $\mathrm{PGE}_{2}$ is increased in bodily fluids. The principle of $\mathrm{PGE}_{2}$ immunoassay is that $\mathrm{PGE}_{2}$ from culture medium competes with horseradish peroxidase (HRP)labeled PGE 2 . After both $\mathrm{PGE}_{2}$ and HRP-labeled $\mathrm{PGE}_{2}$ bind to the antibody sites, a substrate solution is added to evaluate the bound enzyme activity. The concentration of $\mathrm{PGE}_{2}$ present in the sample is inversely proportional to the intensity of the color at the end of the immunoassay.

\section{Gene expression analysis}

$\boldsymbol{R N A}$ extraction: Culture medium was removed after 4 or 5 hours of incubation. $300 \mu \mathrm{L}$ lysis buffer was added per $10^{6}$ cells. Then, $100 \mu \mathrm{L}$ of protein/DNA precipitating buffer was mixed and centrifuged to remove the protein and DNA. Supernatant was removed to new eppendorf tube and mixed with $300 \mu \mathrm{L}$ isopropanol. The tube was put in $-70{ }^{\circ} \mathrm{C}$ freezer for more than 24 hours to precipitate RNA. RNA pellet was washed by $70 \%$ ethanol and then dissolved in DEPC-water. For tissue samples, TriReagent (Sigma) was used to homogenize the tissue samples in homogenizers. Chloroform was added to remove DNA and protein. After centrifugation, the water phase was removed to a new tube and 1 volume isopropanol was mixed to precipitate RNA. RNA was washed by $70 \%$ ethanol to remove isopropanol and dissolved into DEPC-water. The concentration of extracted RNA was quantitated by measuring the absorption in $\mathrm{OD}_{260}$ and $\mathrm{OD}_{280}$ in spectrophotometer. The ratio of $\mathrm{OD}_{260} / \mathrm{OD}_{280}$ is between 1.6 to 1.8 for samples were used for the following experiments.

cDNA synthesis: Total RNA extracted from cultured cells and tissue samples were used as template for reverse transcription. $300 \mathrm{ng}$ total RNA was added to $25 \mu \mathrm{L}$ total volume of reaction mix containing 0.6 mM dNTPs (Promega), 10 units Rnase inhibitor (Clonetech), O1igo(dT) 15 primer (Promega) and 100 units of MMLV-RT (Promega). The whole reaction mix was incubated for 20 minutes at $42^{\circ} \mathrm{C}$. Then, the activity of reverse transcriptase was stopped via heating at $94^{\circ} \mathrm{C}$ for 5 minutes. The synthesized cDNA was chilled on ice immediately for PCR reaction or stored at $-70^{\circ} \mathrm{C}$ for later analysis. 
Real time PCR Analysis: The production of PCR products was determined by measuring the SYBR Green fluorescence signal. SYBR Green DNA enters small, large cavities in double strands. The unbound dye in the solution emits very low fluorescence. However, as the binding of SYBR Green to DNA increases, the fluorescence emission at a wavelength of $530 \mathrm{~nm}$ rises. During PCR, the increase in SYBR Green fluorescence composition increases with the proportion of directly produced double-stranded DNA. Real time quantitative PCR was applied in the direction of the manufacturer using the Invitrogen Universal EXPRESS SYBR Greener qPCR SuperMixes, Two-Step qRT-PCR kit on the Roche LightCycler 480 II device and primers and probes suitable for the gene region (17). In our study, $\beta$ actin gene was used as the house-keeping gene. Concentration values of $i N O S$ and COX-2 gene expression of each sample were proportional to the concentration of $\beta$-actin of the same sample. The obtained values were multiplied by 100 and gene expression levels were calculated for each sample and the results obtained were compared. Relative quantitation was also used when expression changes were calculated and the expression of $i N O S$ and COX-2 genes in LPS and different concentration of hyperforin and hypericin treated RAW 264.7 macrophages was expressed as folds, assuming gene expression values 1 in no-treatment controls.

\section{Statistical analysis}

All experiments were repeated three times. The values were determined as mean \pm standard deviation (SD). SPSS (version 15.0 for windows) was used for determining the treatment effects by

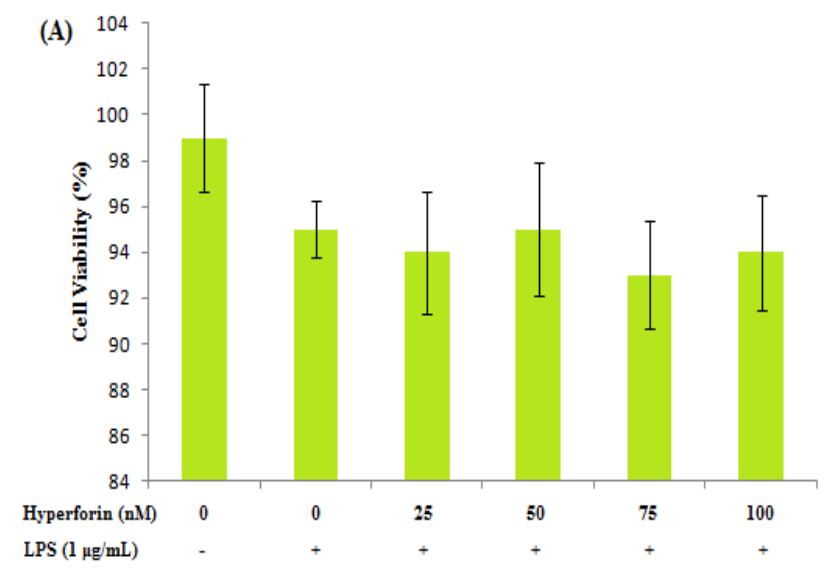

one-way ANOVA. The difference or correlation was considered to be statistically significant if $\mathrm{p}$ $<0.05$ in the obtained results.

\section{Results}

Cytotoxicity of hyperforin and hypericin in RAW 264.7 macrophages

Prior to evaluation of the $\mathrm{NO}$ and $\mathrm{PGE}_{2}$ inhibitory effect of hyperforin and hypericin, we first examined its cytotoxic effect in RAW 264.7 macrophages using MTT assays (Fig. 1a and 1b). While, hyperforin did not influence the survival of RAW 264.7 macrophages at concentrations of 25 , 50, 75 and $100 \mathrm{~nm}$, hypericin did not influence the survival of RAW 264.7 cells at concentrations of 2.5, 5, 7.5 and $10 \mu \mathrm{M}$. Thus, these concentrations were used in subsequent experiments.

\section{Effects of hyperforin and hypericin on NO and $\mathrm{PGE}_{2}$ production in RAW 264.7 macrophages}

We investigated the potential anti-inflammatory effect of hyperforin and hypericin on $\mathrm{NO}$ and $\mathrm{PGE}_{2}$ production in RAW 264.7 macrophages. As shown in Fig. $2 \mathrm{a}$ and $2 \mathrm{~b}, \mathrm{NO}$ production and in Fig. 2c and 2d, PGE 2 production was substantially higher in LPS-treated cells than in the untreated control cells $(\mathrm{p}<0.001)$. The addition of $25,50,75$ and $100 \mathrm{~nm}$ hyperforin caused $42.68 \%, 47.49 \%$, $56.37 \%$ and $58.11 \%$ reduction and the addition of 2.5, 5, 7.5 and $10 \mu \mathrm{M}$ hypericin caused $37.69 \%$, $41.66 \%, 44.69 \%$ and $53.63 \%$ reduction in LPSinduced NO production, respectively (Fig. 2a and 2b). While, 25, 50, 75 and $100 \mathrm{~nm}$ hyperforin caused $8.14 \%, \quad 10.04 \%, \quad 31.24 \%$ and $56.72 \%$

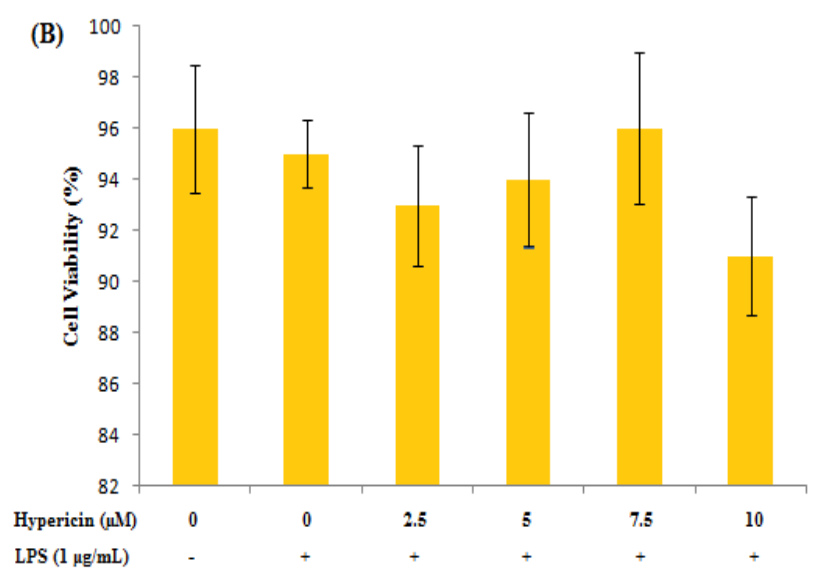

Fig. 1. Effect of hyperforin and hypericin on the cell viability of RAW 264.7 macrophage cells. Cells were incubated with various concentrations of hyperforin (a) and hypericin (b) for $48 \mathrm{~h}$, and then cell viability was determined by MTT assay. The results are expressed as mean \pm SD of five independent experiments. There was no statistically difference between the groups $(\mathrm{p}>0.05)$. 
reduction in LPS-induced $\mathrm{PGE}_{2}$ production, 2.5, 5, 7.5 and $10 \mu \mathrm{M}$ hypericin caused $5.98 \%, 16.45$ $\%, 38.53 \%$ and $53.37 \%$ reduction in LPS-induced $\mathrm{PGE}_{2}$ production, respectively (Fig $2 \mathrm{c}$ and $2 \mathrm{~d}$ ).

Effect of hyperforin and hypericin on iNOS and $C O X-2$ mRNA expression in LPSstimulated RAW 264.7 cells

RT-PCR was performed to determine whether the inhibitory effects of hyperforin and hypericin on $\mathrm{NO}$ and $\mathrm{PGE}_{2}$ production were related to the mRNA expression of $i N O S$ and COX-2. As shown in Fig. $3 \mathrm{a}$ and $3 \mathrm{~b}$, iNOS mRNA expression and in Fig. $3 \mathrm{c}$ and $3 \mathrm{~d}, C O X-2$ mRNA expression was substantially higher in LPS-treated cells than in the untreated control cells $(\mathrm{p}<0.001)$. The addition of $25,50,75$ and $100 \mathrm{~nm}$ hyperforin caused $48 \%, 59 \%, 64 \%$ and $69 \%$ reduction and the addition of $2.5,5,7.5$ and $10 \mu \mathrm{M}$ hypericin caused $37 \%, 42 \%, 48 \%$ and $57 \%$ reduction in LPS-induced iNOS mRNA expression, respectively (Fig. 3a and 3b). While, 25, 50, 75 and $100 \mathrm{~nm}$ hyperforin caused $44 \%, 59 \%, 64 \%$ and $78 \%$ reduction in LPS-induced COX-2 mRNA
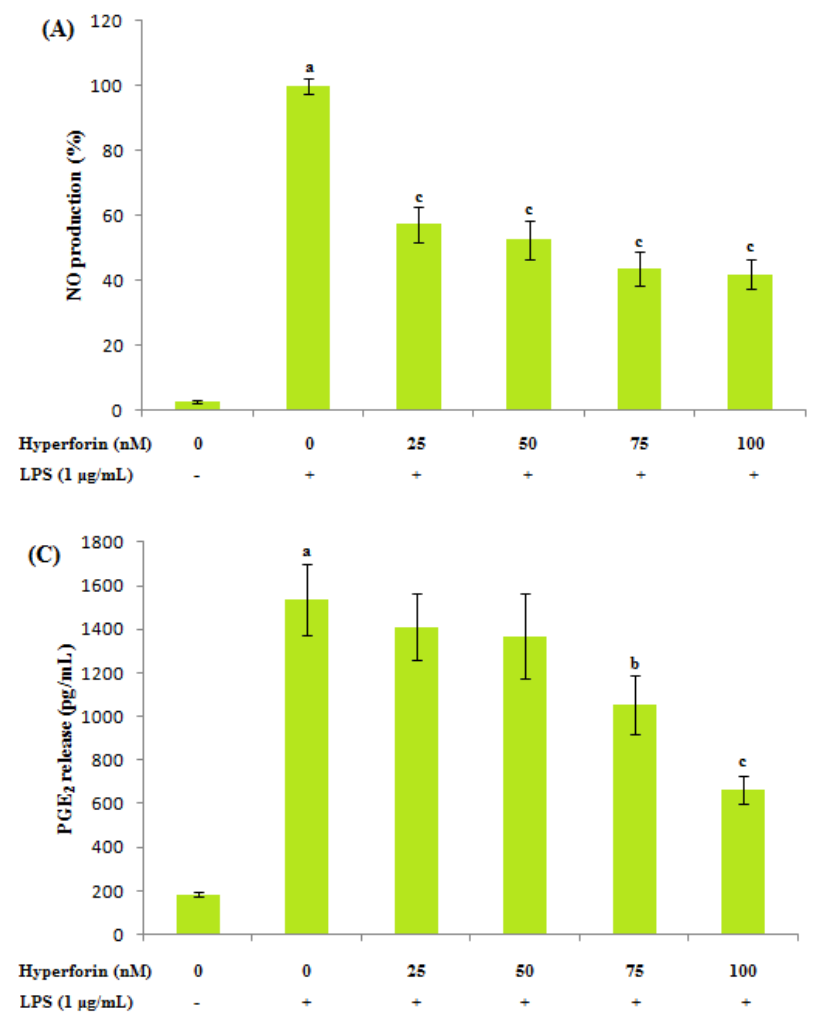

expression, 2.5, 5, 7.5 and $10 \mu \mathrm{M}$ hypericin caused $42 \%, 49 \%, 56 \%$ and $65 \%$ reduction in LPSinduced COX-2 mRNA expression, respectively (Fig. 3c and 3d).

\section{Discussion}

Most of the previous studies on Hypericum perforatum have focused on their chemical constituents, antidepressive, anti-microbial, and anti-cancer effects. Traditional use of Hypericum perforatum includes wound healing and resolving infection, which could result from potential anti-inflammatory properties $(13,14)$.

In vitro cell culture studies have been done to evaluate various Hypericum perforatum preparations and their contents against inflammatory mediator production $(13,14)$. Bezakova et al. (18) reported inhibition of 12-lipoxygenase by hypericin and pseudohypericin in a Hypericum perforatum extract. This inhibition could limit the substrate supply for lipid inflammatory mediator synthesis. Tedeschi et al. (19) treated A549 human alveolar epithelial cells, DLD-1 human colon carcinoma cells and
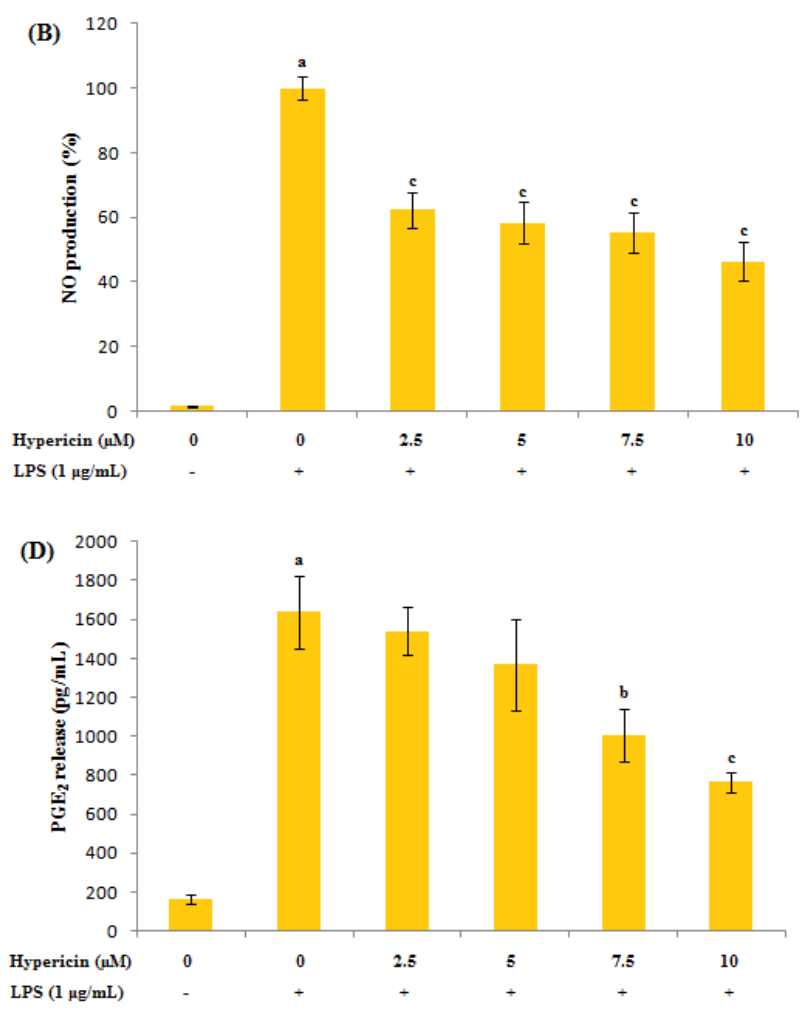

Fig. 2. Effects of hyperforin and hypericin on LPS-induced NO and PGE 2 production in RAW 264.7 macrophages. NO production of cells pretreated with different concentrations of hyperforin (a) and hypericin (b) for $1 \mathrm{~h}$, then with LPS $(1 \mu \mathrm{g} / \mathrm{mL})$, and incubated for $48 \mathrm{~h}$. PGE 2 production of cells pretreated with different concentrations of hyperforin (c) and hypericin (d) for $1 \mathrm{~h}$, then with LPS (1 $\mu \mathrm{g} / \mathrm{mL})$, and incubated for $48 \mathrm{~h}$. The results are expressed as mean $\pm \mathrm{SD}$ of five independent experiments.

${ }^{\mathrm{a}} \mathrm{p}<0.05$ as compared with the control cells, and ${ }^{\mathrm{b}} \mathrm{p}<0.05,{ }^{\mathrm{c}} \mathrm{p}<0.001$ as compared with the LPS-only treated cells. ANOVA and Tukey's post-hoc test were used to determine the significances of differences. 

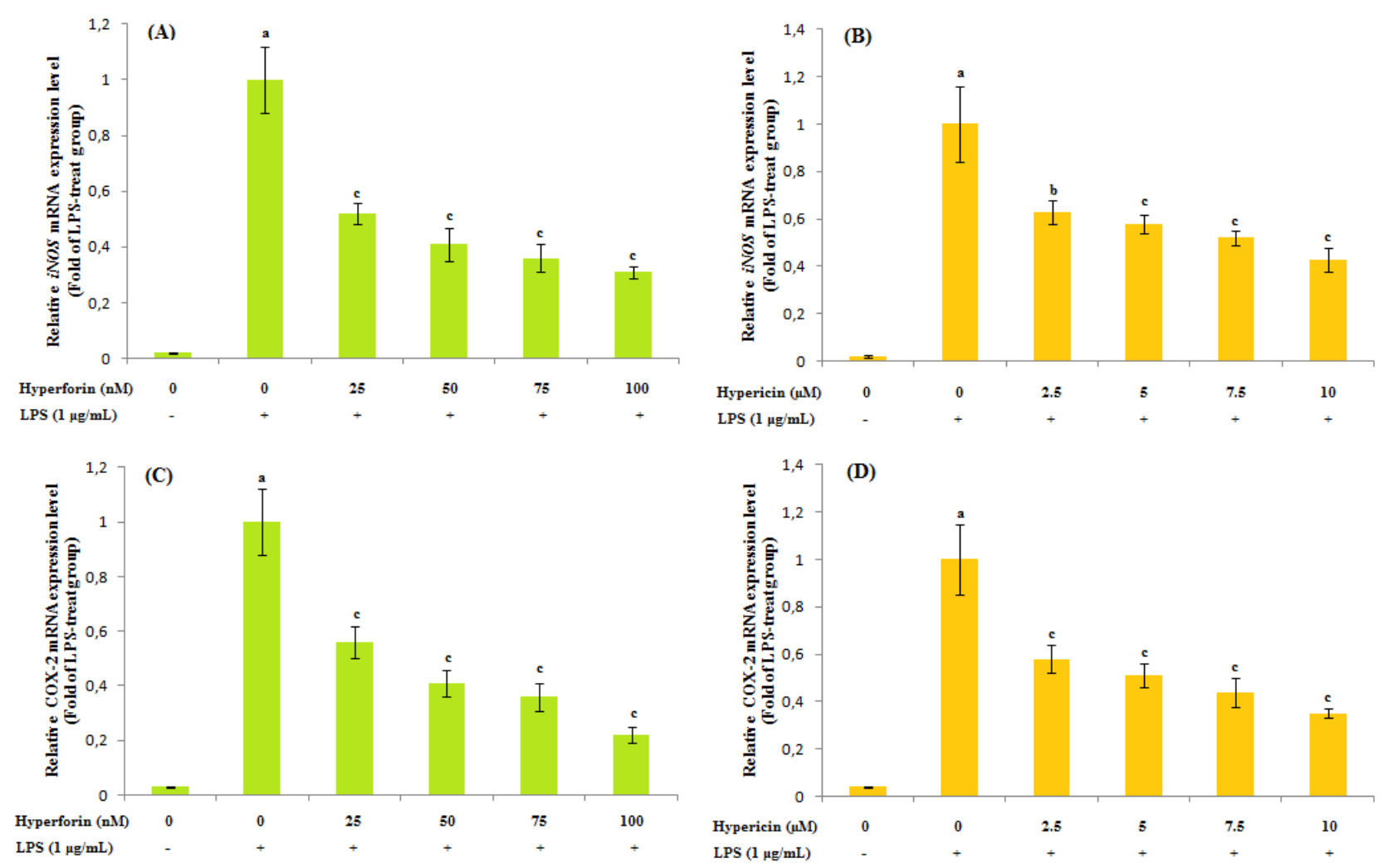

Fig. 3. Effects of hyperforin and hypericin on LPS-induced iNOS and COX-2 gene expression in RAW 264.7 macrophages. iNOS gene expression of cells pretreated with different concentrations of hyperforin (a) and hypericin (b) for $1 \mathrm{~h}$, then with LPS $(1 \mu \mathrm{g} / \mathrm{mL})$, and incubated for $48 \mathrm{~h}$. COX-2 gene expression of cells pretreated with different concentrations of hyperforin (c) and hypericin (d) for $1 \mathrm{~h}$, then with LPS (1 $\mu \mathrm{g} / \mathrm{mL})$, and incubated for $48 \mathrm{~h}$. The results are expressed as mean $\pm \mathrm{SD}$ of five independent experiments.

${ }^{a} \mathrm{p}<0.05$ as compared with the control cells, and ${ }^{b} \mathrm{p}<0.05,{ }^{c} \mathrm{p}<0.001$ as compared with the LPS-only treated cells. ANOVA and Turkey's post-hoc test were used to determine the significances of differences.

ECV304 human cells with various doses of a commercially available Hypericum perforatum extract. Expression of iNOS gene, its catalytic product NO, as well as STAT-1 protein were found to be decreased at a dose as low as $10 \mu \mathrm{g} / \mathrm{mL}$. The authors also noted that direct inhibition of JAK2 was the mechanism, instead of alteration of NF- $x \mathrm{~B}$. Some studies found immune-stimulatory activity of Hypericum perforatum constituents. Zhou et al. (20) treated human intestine epithelial cells and hepatocytes with hyperforin and found increased IL-8 mediated by MAPK activation. Hypericin has also been shown to promote the expression of COX-2 protein at respectively low concentrations of $125 \mathrm{nM}$ and $150 \mathrm{nM}$ in HeLa and T24 cells.

Animal studies were conducted to test the in vivo antiinflammatory potential of Hypericum perforatum extract and their major active constituents. Abdel-Salam (21) evaluated the impact of orally administrated Hypericum perforatum extract (50-300 mg/ kg body weight) on rats with carrageen-induced edema, electrically or hot plate induced nociception, and pylorus-ligation. The results indicated strong inhibition of the pain associated with inflammation by the extract. Hu et al. (22) used irinotecan to induce intestinal inflammation and diarrhea in rats, with or without an 8 day treatment regimen of $400 \mathrm{mg} / \mathrm{kg}$ Hypericum perforatum extract. Those rats that received treatment had less apoptosis in the intestine, with lower TNF-a mRNA expression. Menegazzi et al. (23) reported that Hypericum perforatum extract treatment protected mice against zymogen-induced multi-organ failure by reducing iNOS expression and scavenging NO.

Zdunic et al. (24) studied the anti-inflammatory and gastroprotective activity of Hypericum perforatum oil extracts in rat models. The results suggested flavonoids, specifically quercetin and amentoflavone, contributed to the observed inhibition of paw edema and intestine mucosa damage. Paterniti et al. (25) comprehensively investigated the impact of a Hypericum perforatum extract during periodontitis. The extract used contained $0.34 \%$ hypericin, $4.1 \%$ hyperforin, 5\% flavonoids, and 10\% tannins. $2 \mathrm{mg} / \mathrm{kg}$ daily oral dose was applied to mice and lasted eight 
days. By the end of the study, iNOS expression, NF$x \mathrm{~B}$ activation, IL-1 $\beta$ and ICAM-1 levels were inhibited in the treatment group, with less severe tissue damage and alveolar bone loss than was observed in the control group.

Our study has shown that all applied concentrations of hyperforin and hypericin decreased LPS-induced NO production and $i N O S$ and COX-2 gene expression in RAW 264.7 macrophages, significantly. Similarly, all applied concentration of hyperforin and hypericin decreased LPS-induced $\mathrm{PGE}_{2}$ production but only 75 and $100 \mathrm{~nm}$ hyperforin and 7.5 and $10 \mu \mathrm{M}$ hypericin decreased $\mathrm{PGE}_{2}$ production significantly. This indicates that hyperforin and hypericin inhibited LPS-induced $\mathrm{NO}$ and $\mathrm{PGE}_{2}$ production and $i N O S$ and $C O X-2$ gene expression in RAW 264.7 macrophages in a dose-dependent manner, indicating that the inhibition of $\mathrm{NO}$ and $\mathrm{PGE}_{2}$ production by hyperforin and hypericin is a result of the inhibition of $i N O S$ and COX-2 gene expression.

In conclusion, the present study showed that hyperforin and hypericin isolated from Hypericum perforatum inhibits inflammation via suppressing iNOS and $\mathrm{COX}-2$ gene expression and $\mathrm{NO}$ and $\mathrm{PGE}_{2}$ production. For this reason, it is possible to say that hypericin and hyperforin can be used to reduce the inflammatory response, but molecular mechanisms underlying the anti-inflammatory potential of Hypericum perforatum and its active constituents were not well-characterized. Although gene transcription profile change under Hypericum perforatum treatment was described using murine cells and yeast, the regulatory pathways that lead to the transcriptome change remains yet to be revealed. Future studies on the anti-inflammatory activity of all the contents of Hypericum perforatum need to address the connection between multiple phytochemical components, bioactivity, the molecular mechanisms, and probably the overall outcome in animal models that better mimic actual inflammatory diseases.

\section{References}

1. Khan AA, Iadarola M, Yang HY, Dionne RA. Expression of COX-1 and COX-2 in a clinical model of acute inflammation. J Pain 2007; 8(4): 349-354.

2. Oto G, Ozdemir H, Yaren B, Yetkin Y, Tas A, Tanritanir P, et al. Antinociceptive activity of methanol extract of Hyoscyamus reticulatus $\mathrm{L}$. in mice. AJPCT 2013; 1(2): 117-123.

3. Murray PJ, Wynn TA. Protective and pathogenic functions of macrophage subsets. Nat Rev Immunol 2011; 11(11): 723-737.
4. Linehan SA, Martínez-Pomares L, Gordon S. Macrophage lectins in host defence. Microbes Infect 2000; 2(3): 279-288.

5. Rietschel ET, Brade H. Bacterial endotoxins. Sci Am 1992; 267(2): 54-61.

6. Korhonen R, Lahti A, Kankaanranta H, Moilanen E. Nitric oxide production and signaling in inflammation. Curr Drug Targets Inflamm Allergy 2005; 4(4): 471-479.

7. Kim SF, Huri DA, Snyder SH. Inducible nitric oxide synthase binds, S-nitrosylates, and activates cyclooxygenase-2. Science 2005; 310(5756): 1966 1970.

8. Baker PR, Schopfer FJ, O'Donnell VB, Freeman BA. Convergence of nitric oxide and lipid signaling: anti-inflammatory nitro-fatty acids. Free Radic Biol Med 2009; 46(8): 989-1003.

9. Korbecki J, Baranowska-Bosiacka I, Gutowska I, Chlubek D. The effect of reactive oxygen species on the synthesis of prostanoids from arachidonic acid. J Physiol Pharmacol 2013; 64(4): 409-421.

10. Seo S, Lee KG, Shin JS, Chung EK, Lee JY, Kim $\mathrm{HJ}$, et al. 6'-O-Caffeoyldihydrosyringin isolated from Aster glehni suppresses lipopolysaccharideinduced iNOS, COX-2, TNF- $\alpha$, IL- $1 \beta$ and IL-6 expression via $\mathrm{NF}-x \mathrm{~B}$ and $\mathrm{AP}-1$ inactivation in RAW 264.7 macrophages. Bioorg Med Chem Lett 2016; 26(19): 4592-4598.

11. Aksu S, Altınterim B. Kantaron otu (Hypericum perforatum) ve hiperisin. Bil Genç Derg 2015; 3(1): 58-64.

12. Oliveira AI, Pinho C, Sarmento B, Dias AC. Neuroprotective activity of Hypericum perforatum and its major components. Front Plant Sci 2016; 7: 1004.

13. Albert D, Zündorf I, Dingermann T, Müller WE, Steinhilber D, Werz O. Hyperforin is a dual inhibitor of cyclooxygenase-1 and 5-lipoxygenase. Biochem Pharmacol 2002; 64(12): 1767-1775.

14. Sosa S, Pace R, Bornancin A, Morazzoni P, Riva A, Tubaro A, et al. Topical anti-inflammatory activity of extracts and compounds from Hypericum perforatum L. J Pharm Pharmacol 2007; 59(5): 703-709.

15. Gentile C, Allegra M, Angileri F, Pintaudi AM, Livrea MA, Tesoriere L. Polymeric proanthocyanidins from Sicilian pistachio (Pistacia vera L.) nut extract inhibit lipopolysaccharide-induced inflammatory response in RAW 264.7 cells. Eur J Nutr 2012; 51(3): 353-363.

16. Green LC, Wagner DA, Glogowski J, Skipper PL, Wishnok JS, Tannenbaum SR. Analysis of nitrate, nitrite, and nitrate in biological fluids. Anal Biochem 1982; 126(1): 131-138.

17. An HJ, Kim IT, Park HJ, Kim HM, Choi JH, Lee KT. Tormentic acid, a triterpenoid saponin, isolated from Rosa rugosa, inhibited LPS-induced iNOS, COX-2, and TNF- $\alpha$ expression through inactivation of the nuclear factor- $x \mathrm{~B}$ pathway in RAW 264.7 macrophages. Int Immunopharmacol 2011; 11(4): 504-510. 
18. Bezáková L, Psenák M, Kartnig T. Effect of dianthrones and their precursors from Hypericum perforatum L. on lipoxygenase activity. Pharmazie 1999; 54(9): 711.

19. Tedeschi E, Menegazzi M, Margotto D, Suzuki H, Förstermann U, Kleinert H. Anti-inflammatory actions of St. John's wort: inhibition of human inducible nitric-oxide synthase expression by downregulating signal transducer and activator of transcription-1alpha (STAT-1alpha) activation. J Pharmacol Exp Ther 2003; 307(1): 254-261.

20. Zhou C, Tabb MM, Sadatrafiei A, Grün F, Sun A, Blumberg B. Hyperforin, the active component of St. John's wort, induces IL-8 expression in human intestinal epithelial cells via a MAPKdependent, NF-kappaB-independent pathway. J Clin Immunol 2004; 24(6): 623-636.

21. Abdel-Salam OME. Anti-inflammatory, antinociceptive, and gastric effects of Hypericum perforatum in rats. Sci World J 2005; 5: 585-595.
22. Hu ZP, Yang XX, Chan SY, Xu AL, Duan W, Zhu YZ, et al. St. John's wort attenuates irinotecan-induced diarrhea via down-regulation of intestinal pro-inflammatory cytokines and inhibition of intestinal epithelial apoptosis. Toxicol Appl Pharmacol 2006; 216(2): 225-237.

23. Menegazzi M, Di Paola R, Mazzon E, Muià C, Genovese T, Crisafulli C, et al. Hypericum perforatum attenuates the development of carrageenan-induced lung injury in mice. Free Radic Biol Med 2006; 40(5): 740-753.

24. Zdunić G, Godevac D, Milenković M, Vucićević D, Savikin K, Menković N, et al. Evaluation of Hypericum perforatum oil extracts for an antiinflammatory and gastroprotective activity in rats. Phytother Res 2009; 23(11): 1559-1564.

25. Paterniti I, Briguglio E, Mazzon E, Galuppo M, Oteri G, Cordasco G, et al. Effects of Hypericum perforatum, in a rodent model of periodontitis. BMC Complement Altern Med 2010; 10: 73. 